\title{
REMEDIATION OF Pb-CONTAMINATED SOILS IN THE GUADIAMAR RIVER BASIN (SW SPAIN)
}

\author{
J. AGUILAR*, C. DORRONSORO, E. FERNÁNDEZ, J. FERNÁNDEZ, I. GARCÍA, \\ F. MARTÍN and M. SIMÓN \\ Departamento de Edafología y Química Agrícola, Facultad de Ciencias, Universidad de Granada, \\ Granada, Spain \\ (*author for correspondence, e-mail: aguilar@ugr.es, Fax: +34 958 244160)
}

(Received 11 November 2002; accepted 24 July 2003)

\begin{abstract}
Soil remediation has been studied after a spill from a settling pond of a pyrite mine in Aznalcóllar (SW Spain). The affected area was approximately $55 \mathrm{~km}^{2}$ and extended about $40 \mathrm{~km}$ from the spill. The $\mathrm{Pb}$ concentration in soils ranged from 35.8 to $3231.0 \mathrm{mg} \mathrm{kg}^{-1}$, with a mean value of $385.8 \mathrm{mg} \mathrm{kg}^{-1}$. The remediation techniques investigated included: manual and mechanical removal of the contaminated soil, mixing the upper part of the soils by ploughing, and addition of different amendment materials to reduce the $\mathrm{Pb}$ solubility, such as carbonates, zeolites, iron-rich soils, bentonites and yeasts. A combination of liming with iron-rich soils proved the most effective treatment.
\end{abstract}

Keywords: Guadiamar river, lead, soil contamination, soil remediation

\section{Introduction}

On 25 April 1998 the holding pond of a pyrite mine in Aznalcóllar, SW Spain (Figure 1), broke open, spilling $36 \times 10^{5} \mathrm{~m}^{3}$ of acidic water and $9 \times 10^{5} \mathrm{~m}^{3}$ of toxic tailings into the Guadiamar river basin, affecting approximately $55 \mathrm{~km}^{2}$ (Simón et al., 1998). The main affected soils, Fluvisols and Regosols (CSIC-IARA, 1998), were covered with a layer of tailings averaging $7 \mathrm{~cm}$ thick and containing high concentrations of $\mathrm{Zn}, \mathrm{Cu}, \mathrm{Cd}, \mathrm{As}, \mathrm{Pb}, \mathrm{Sb}, \mathrm{Bi}$ and $\mathrm{Tl}$.

The soils were polluted in two stages. First, tailings and acidic waters covered and penetrated the soils; approximately $75 \%$ of the $\mathrm{Pb}$ contamination in the soil came from the tailings, whereas the remaining $25 \%$ was attributed to the acidic waters (Simón et al., 1999). In the second stage, the oxidation of the pyrite tailings released high concentrations of $\mathrm{Pb}$ which entered the soil and increased $\mathrm{Pb}$ content in the uppermost $10 \mathrm{~cm}$ by two- to three-fold (Simón et al., 2001). Four months after the spill, the tailings were removed from the upper part of the soils using heavy machinery. However, both the action of the machinery and the rainfall during this period caused the tailings to penetrate the soils, increasing pollution with a highly irregular distribution pattern.

Whereas the $\mathrm{Pb}$ content of uncontaminated soils of the area ranged from 22.0 to $74.6 \mathrm{mg} \mathrm{kg}^{-1}$, with a mean of $41.8 \mathrm{mg} \mathrm{kg}^{-1}$, (Simón et al., 1999), the contaminated 


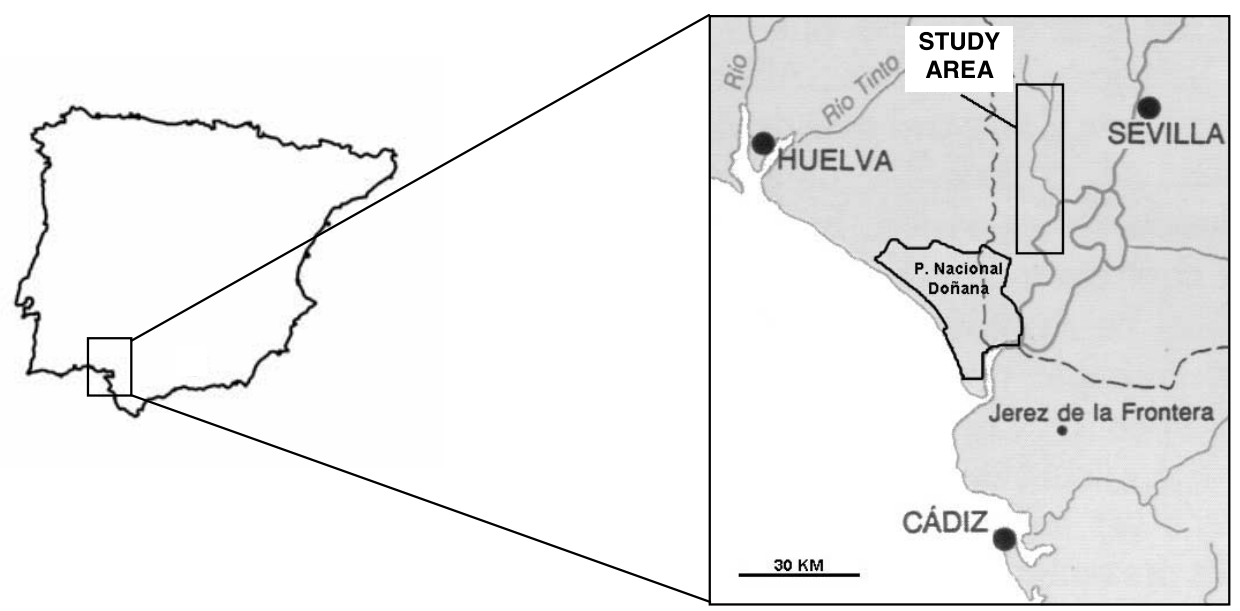

Figure 1. Location of the study area.

soils, after the removal of tailings (the first remediation measure), registered a mean $\mathrm{Pb}$ concentration of $204.1 \mathrm{mg} \mathrm{kg}^{-1}$ in the upper $50 \mathrm{~cm}$, and $385.8 \mathrm{mg} \mathrm{kg}^{-1}$ (35.8$3231.0 \mathrm{mg} \mathrm{kg}^{-1}$ ) in the uppermost $10 \mathrm{~cm}$.

The aim of the present work is to assess the pollution of soils in the Guadiamar river basin and seek remediation measures appropriate to local conditions (Mediterranean climate in flood-plain soils).

\section{Materials and Methods}

The study area is located on the Guadiamar river flood plain affected by the spill (Figure 1). The mean annual temperature is $17.7^{\circ} \mathrm{C}$, the mean annual precipitation exceeds slightly $600 \mathrm{~mm}$, and the potential evapotranspiration values reach $900 \mathrm{~mm}$. Thus, the temperature regime is thermic and the moisture regime xeric (USDA, 1999).

The total contamination was sudied with a sampling network established on a grid of $400 \times 400 \mathrm{~m}$ covering the affected area. At each intersection and in the centre of each cell, a square $(10 \times 10 \mathrm{~m})$ was sampled ( 4 corners and centre pooled) at three depths: $0-10,10-30$ and $30-50 \mathrm{~cm}$.

Two laboratory experiments and one field experiment were performed to analyse the possible remediation measures.

(1) Neutralization tests: In the laboratory, increasing amounts of carbonate materials (cellulose ash, sugar-refinery scum, sewage sludge, pure $\mathrm{CaCO}_{3}$ ) were added to a contaminated soil of the area, until approaching soil $\mathrm{pH}$ 7. Afterwards, the tailings from the same contaminated soil were oxidized with $\mathrm{H}_{2} \mathrm{O}_{2}$ 


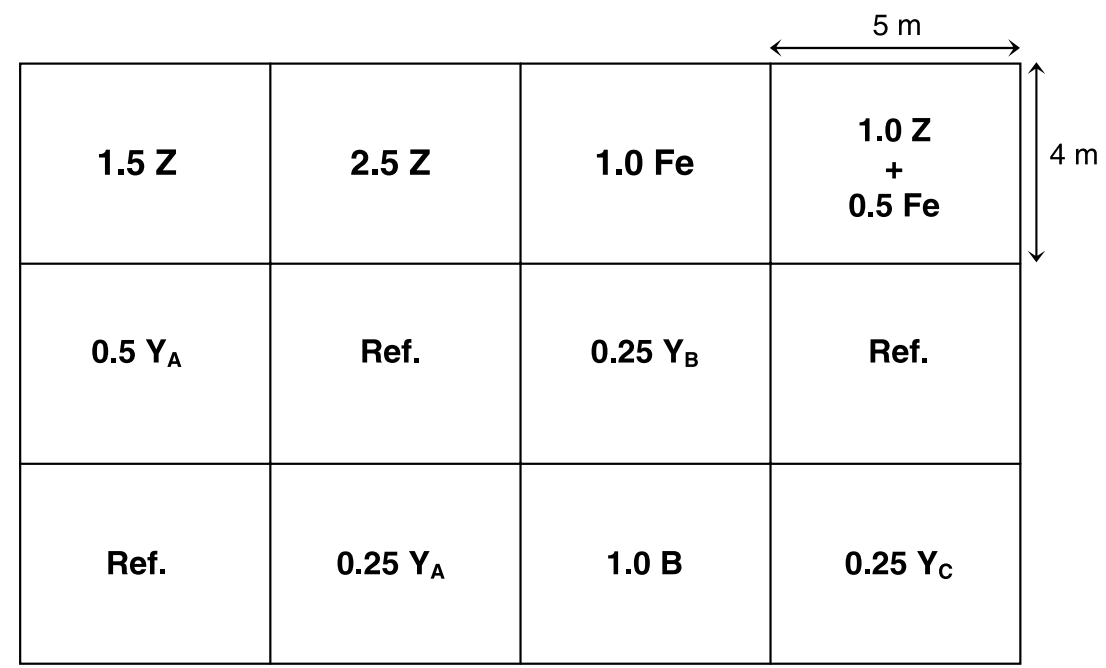

Figure 2. Application scheme of the field experiment (amendment materials: $\mathrm{Fe}=$ iron oxides, $\mathrm{Z}=$ zeolites, $\mathrm{B}=$ bentonites, $\mathrm{Y}=$ yeasts type $\mathrm{A}, \mathrm{B}$ and $\mathrm{C}$; the number accompanying the symbol indicates the application rate in $\mathrm{kg} \mathrm{m}^{-2}$; Ref. = reference plots, untreated).

(5 g soil $+100 \mathrm{~mL} \mathrm{H}_{2} \mathrm{O}_{2}$ at $15 \%$ ), and neutralized with increasing amounts of cellulose ash.

(2) Soil-properties test: In the laboratory, soil properties were evaluated with respect to $\mathrm{Pb}$ retention. Different soil samples (2 replicates) were selected as characteristic of a given soil property: $\mathrm{pH}, \mathrm{CaCO}_{3}$, organic matter $(\mathrm{OM})$, clay, free-iron $\left(\mathrm{Fe}_{d}\right)$. A pollutant solution was prepared by adding $1000 \mathrm{~cm}^{3}$ of $\mathrm{H}_{2} \mathrm{O}_{2}$ (15\%) to $10 \mathrm{~g}$ of tailings from the area (Urrutia et al., 1992). Afterwards, $25 \mathrm{~mL}$ of this pollutant solution were added to $2.5 \mathrm{~g}$ of each soil sample, and the mixture was shaken for three days. $\mathrm{Pb}$ retention by soils was determined as the difference between the $\mathrm{Pb}$ concentration in the initial pollutant solution and the final soil-sample solution.

(3) Field experiment: In one of the most polluted sectors (Vicario), test plots of $4 \times 5 \mathrm{~m}$ were treated with different amounts of various amendment materials: iron oxides $(\mathrm{Fe})$, zeolite $(\mathrm{Z})$, bentonite $(\mathrm{B})$ and yeasts $(\mathrm{Y})$. The application scheme appears in Figure 2. In each plot, samples (collected from 5 sampling points) were taken on three different dates in 1999 (29 March, 17 May and 29 September) and total, water-soluble and EDTA-extractable $\mathrm{Pb}$ were analysed.

Field descriptions of soils were based on the Soil Survey Staff (1951). Particlesize distribution was determined by the pipette method after elimination of organic matter with $\mathrm{H}_{2} \mathrm{O}_{2}$ and dispersion with sodium hexametaphosphate (Loveland and Whalley, 1991). The $\mathrm{pH}$ was measured potentiometrically in a 1:2.5 soil:water suspension. The $\mathrm{CaCO}_{3}$ equivalent was determined by the method of Bascomb (1961). Total carbon was analysed by dry combustion with a LECO SC-144DR instrument, 


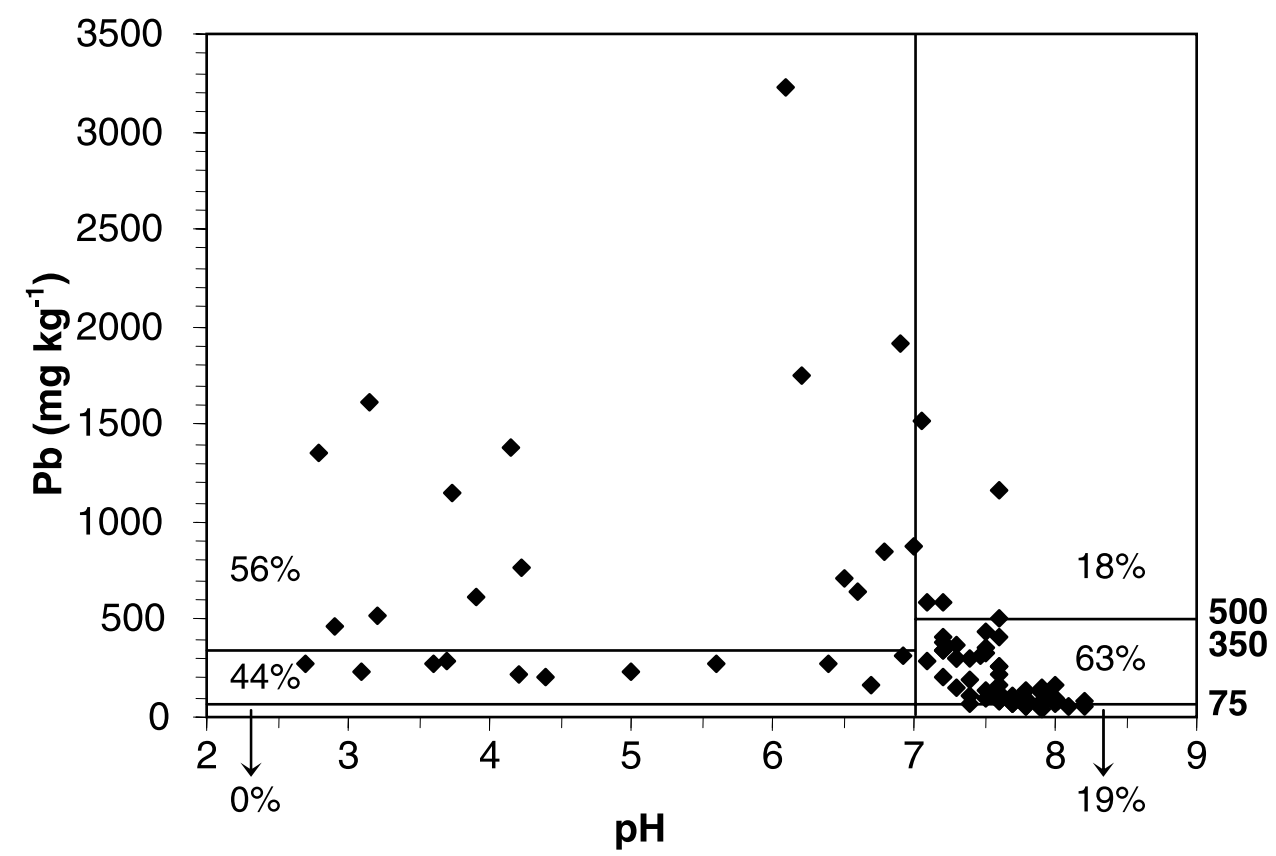

Figure 3. Total $\mathrm{Pb}$ concentration and percentage of soil samples exceeding permitted levels for agricultural soils ( $350 \mathrm{mg} \mathrm{kg}^{-1}$ for $\mathrm{pH}<7$ and $500 \mathrm{mg} \mathrm{kg}^{-1}$ for $\mathrm{pH}>7$ ) and the uncontaminated soils of the area $\left(>75 \mathrm{mg} \mathrm{kg}^{-1}\right)$ after the removal of the tailings.

and organic carbon (OC) estimated as the difference between total carbon and inorganic carbon from $\mathrm{CaCO}_{3}$. Free-iron oxides $\left(\mathrm{Fe}_{d}\right)$ were extracted with citrate dithionite (Holmgren, 1967) and measured by atomic absorption spectroscopy in a Perkin Elmer 305B instrument. Soil samples, finely ground $(<0.05 \mathrm{~mm})$, were digested in strong acids $\left(\mathrm{HNO}_{3}+\mathrm{HF}\right)$ and the $\mathrm{Pb}$ was determined by ICP-MS with a Perkin Elmer Sciex-Elan 5000A spectrometer.

For the speciation of $\mathrm{Pb}$ forms, extractions were made with EDTA (Quevauviller et al., 1998) to estimate the bioavailable $\mathrm{Pb}$ (Sposito et al., 1982), and with distilled water in a soil-water saturation extract to estimate the soluble $\mathrm{Pb}$.

\section{Results and Discussion}

After the analysis of the pyrite spill, limits for $\mathrm{Pb}$ pollution in agricultural soils were posed, taking into account the existing legislation in other countries (GRER, 1996; Kloke et al., 1994; Sheppard et al., 1992; Adriano et al., 1997): $350 \mathrm{mg}$ $\mathrm{kg}^{-1}$ in soils with $\mathrm{pH}<7$ and $500 \mathrm{mg} \mathrm{kg}{ }^{-1}$ for soils with $\mathrm{pH} \geq 7$ (Aguilar et al., 1999). After the tailings were removed, $56 \%$ of the acidic soils and $18 \%$ of the basic soils had $\mathrm{Pb}$ concentrations exceeding these levels (Figure 3). The remaining $44 \%$ of the acidic soils and $63 \%$ of the basic soils surpassed the highest value of the 
TABLE I

Percentage of soil samples in the Guadiamar river basin exceeding permitted levels after the removal of tailings

\begin{tabular}{|c|c|c|c|c|}
\hline & \multirow{2}{*}{$\frac{\text { Natural Park use }^{\mathrm{a}}}{\text { Total Pb }}$} & \multicolumn{3}{|c|}{ Agricultural use } \\
\hline & & Total $\mathrm{Pb}^{\mathrm{b}}$ & Soluble $\mathrm{Pb}^{\mathrm{c}}$ & EDTA $\mathrm{Pb}^{\mathrm{d}}$ \\
\hline $\begin{array}{l}\text { \% Soil samples above } \\
\text { intervention level }\end{array}$ & 15 & 26 & 10 & 25 \\
\hline $\begin{array}{l}1000 \mathrm{mg} \mathrm{kg}^{-1} \\
350 \mathrm{mg} \mathrm{kg}^{-1} \text { for } \mathrm{pH}< \\
1 \mathrm{mg} \mathrm{kg}^{-1} \\
100 \mathrm{mg} \mathrm{kg}^{-1}\end{array}$ & and $500 \mathrm{mg} \mathrm{kg}^{-1}$ & $\mathrm{pH}>7$. & & \\
\hline
\end{tabular}

uncontaminated soils of the area $\left(75 \mathrm{mg} \mathrm{kg}^{-1}\right)$. Based on these results, the Regional Government of Andalusia (Spain) prohibited the agricultural use of these soils.

In the case of soluble $\mathrm{Pb}$, the maximum permitted level, $1 \mathrm{mg} \mathrm{kg}^{-1}$ (Ewers, 1991), was exceeded in $10 \%$ of the soils of the area. For EDTA-extractable $\mathrm{Pb}$, we set a maximum level of $100 \mathrm{mg} \mathrm{kg}^{-1}$ (extrapolated from the limits for total $\mathrm{Pb}$ ), $25 \%$ of the total area surpassing this value. These values (summarized in Table I) clearly indicate the need of soil remediation throughout the basin.

The following remediation measures were considered most appropriate: (a) Cleanup, i.e., further soil removal and reduction of pollution concentration by tilling; (b) $\mathrm{Pb}$ immobilization by liming and adding other amendment materials.

For the cleanup, soils were removed to approximately $10 \mathrm{~cm}$ in the acidic area and tilled to a depth of $25 \mathrm{~cm}$, thereby reducing the mean $\mathrm{Pb}$ concentration in the remaining uppermost $10 \mathrm{~cm}$ from 526.4 to $398.6 \mathrm{mg} \mathrm{kg}^{-1}$. However, despite the substantial reduction, the $\mathrm{Pb}$ content remained too high for agricultural use in large parts of the affected area.

As no further cleanup was feasible, remediation focused on the immobilization of $\mathrm{Pb}$. For this, the soil parameters related to the fixation and retention of $\mathrm{Pb}$ were analysed. Experiments were conducted using soil horizons containing different contents in $\mathrm{OM}$, clay, $\mathrm{CaCO}_{3}, \mathrm{pH}$ and $\mathrm{Fe}_{d}$ (Table II). A solution from the oxidation of tailings ( $\mathrm{Pb}$ concentration $\left.3.20 \mathrm{mg} \mathrm{dm}^{-3}, \mathrm{pH} 1.65\right)$ were added to each sample. The results (Figure 4) show that $\mathrm{Pb}$ was retained in large quantities in all the soil samples, but more effectively in carbonate soils (95-98\%), followed by iron-rich and clayey soils (75-82\%). The soils with the lowest $\mathrm{pH}$ and without carbonates showed the least $\mathrm{Pb}$ retention (8-25\%). According to these results, the most important soil property in $\mathrm{Pb}$ retention in all the soils is $\mathrm{CaCO}_{3}$, and therefore the first recommended measure to immobilize this metal is liming.

The amount of liming would depend on the $\mathrm{CaCO}_{3}$ content, as well as on the $\mathrm{pH}$ and pyritic sulphur content of the soils to be treated. Therefore, different neutralization curves resulted for a contaminated soil from the area ( $\mathrm{pH} 4.0)$ by the 
TABLE II

Characteristics of the soil horizons treated with the pollutant solution prepared from the tailings oxidation

\begin{tabular}{llrcccc}
\hline Soil & $\begin{array}{l}\text { O.M. } \\
(\%)\end{array}$ & $\begin{array}{l}\text { Clay } \\
(\%)\end{array}$ & $\begin{array}{l}\mathrm{CEC} \\
\left(\mathrm{cmol}_{c} \mathrm{~kg}^{-1}\right)\end{array}$ & $\begin{array}{l}\text { Fed } \\
(\%)\end{array}$ & $\mathrm{pH}$ & $\begin{array}{l}\mathrm{CaCO}_{3} \\
(\%)\end{array}$ \\
\hline 11 & 5.20 & 13.3 & 10.23 & 1.08 & 7.56 & 0.0 \\
12 & 4.24 & 13.2 & 8.03 & 1.18 & 7.41 & 0.0 \\
21 & 1.59 & 13.0 & 5.00 & 2.50 & 5.72 & 0.0 \\
22 & 1.93 & 13.3 & 5.49 & 2.15 & 4.86 & 0.0 \\
31 & 2.83 & 8.2 & 5.48 & 1.70 & 7.25 & 0.0 \\
32 & 1.69 & 19.7 & 7.30 & 1.37 & 7.86 & 0.0 \\
41 & 0.69 & 33.1 & 7.30 & 2.47 & 7.20 & 0.0 \\
42 & 0.79 & 57.6 & 13.50 & 3.63 & 7.09 & 0.0 \\
51 & 0.45 & 5.5 & 2.56 & 0.74 & 8.86 & 0.0 \\
52 & 0.55 & 5.1 & 2.56 & 0.55 & 8.60 & 0.0 \\
61 & 0.55 & 5.2 & 2.56 & 0.32 & 9.04 & 22.0 \\
62 & 0.46 & 5.9 & 2.19 & 0.39 & 8.68 & 16.0 \\
\hline
\end{tabular}



Figure 4. Percentage of retained $\mathrm{Pb}$ in the different soil samples of Table II. 


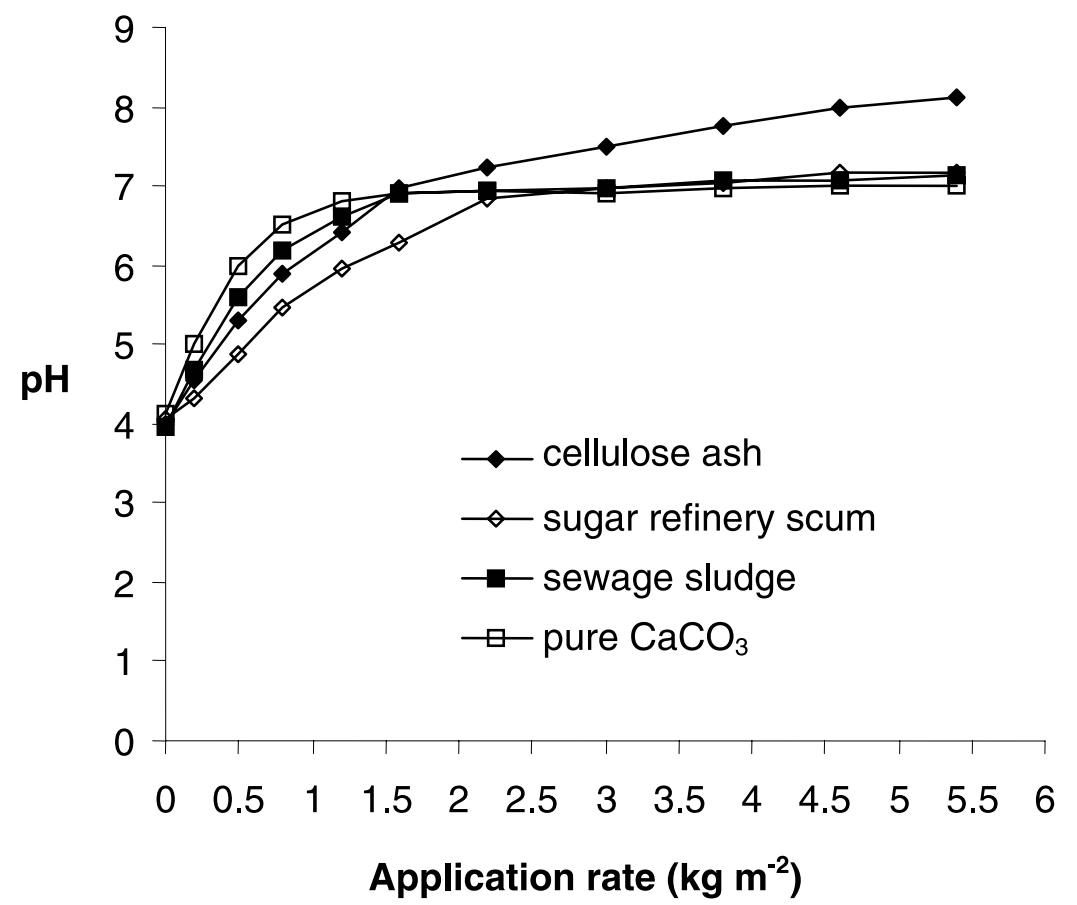

Figure 5. Neutralization curves of an affected soil ( $\mathrm{pH} \mathrm{4)}$ by the addition of increasing amounts of carbonate materials.

addition of different carbonate amendment materials (pure $\mathrm{CaCO}_{3}$, sewage sludge, sugar-refinery scum, and cellulose ash). The soil $\mathrm{pH}$ increased proportionally to the carbonate in the amendment material. Soil neutralization was achieved at application rates of $1.2 \mathrm{~kg} \mathrm{~m}^{-2}$ (pure $\mathrm{CaCO}_{3}$ ) to $2.2 \mathrm{~kg} \mathrm{~m}^{-2}$ (sugar-refinery scum). For cellulose ash and sewage sludge, the neutralization was reached at roughly $1.6 \mathrm{~kg}$ $\mathrm{m}^{-2}$ (Figure 5).

In all cases, pyritic sulphur remained in the soils at a mean concentration of $1.65 \%$, ranging between 0.01 to $10.92 \%$. The progressive oxidation of this sulphur would cause acidification and thereby require a higher rate of liming. To simulate this situation, we induced the total oxidation of sulphur in the soil sample by adding $\mathrm{H}_{2} \mathrm{O}_{2}$, whereupon the liming needed to reach neutrality approached $12 \mathrm{~kg} \mathrm{~m}^{-2}$ in the case of cellulose ash (roughly 8 -fold the initial rate). This result implies that about $2 \mathrm{~kg} \mathrm{~m}^{-2}$ of amendment material, the initial rate applied in many affected areas, would be insufficient to neutralize the potential acidity generated by the oxidation of sulphur in the acidic soils. Therefore, in many soils this treatment should be repeated 6 or 7 times in order to reach stable neutralization (Figure 6).

According to these results, and given that the materials tested had similar neutralization capacities, the use of sugar-refinery scum is recommended for the following reasons: (1) low cost; (2) gradual change in $\mathrm{pH}$ for more efficient $\mathrm{Pb}$ stabilization; (3) restoration of organic matter lost during the cleanup. 


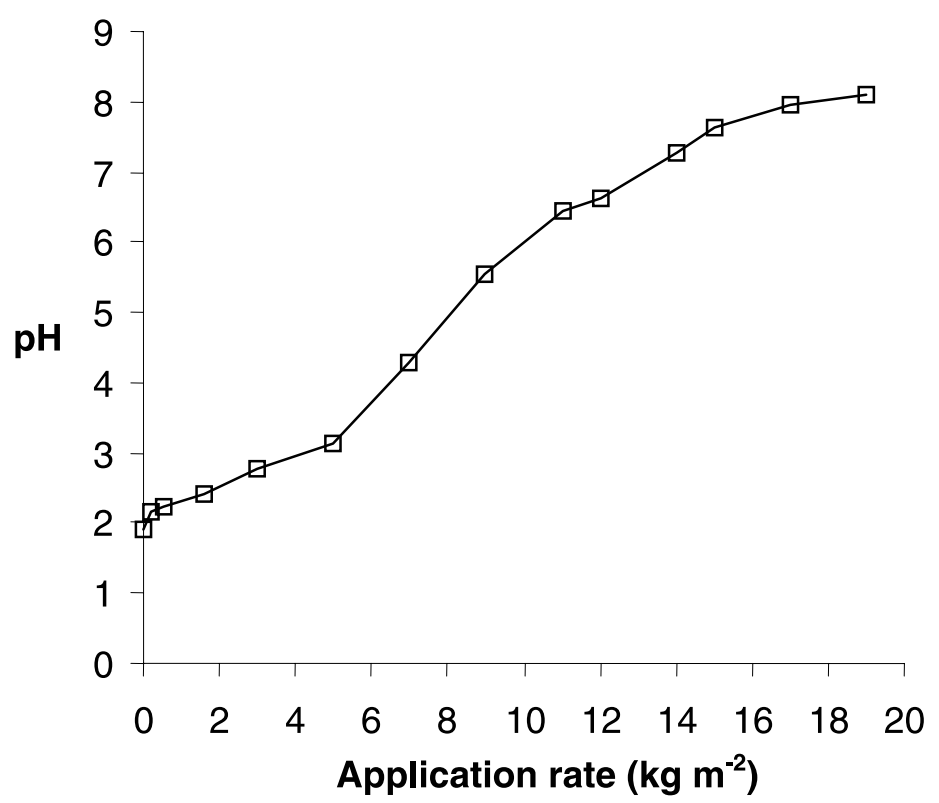

Figure 6. Neutralization curve after total oxidation of sulphur in the same soil sample of Figure 5, by increasing amounts of cellulose ash.

Even with the application of $16 \mathrm{~kg} \mathrm{~m}^{-2}$ of sugar-refinery scum, certain amounts of $\mathrm{Pb}$ would still remain in free forms. One year later, $10 \%$ of the samples treated at this rate had values of soluble $\mathrm{Pb}$ higher than $0.5 \mathrm{mg} \mathrm{kg}^{-1}$, while $25 \%$ of the same samples had values of EDTA-extractable $\mathrm{Pb}$ higher than $100 \mathrm{mg} \mathrm{kg}^{-1}$.

For the identification of other compounds that retain $\mathrm{Pb}, 12$ test plots were laid out in the Vicario sector (northern part of the basin), where the soils have no calcium carbonate. Different amounts of iron, zeolite, bentonite and different types of yeast were added to the plots, without using liming materials. The soils of these plots were analysed for total $\mathrm{Pb}$ before treatment (3 March 1999; Figure 7) and also for soluble $\mathrm{Pb}$ three times afterwards (29 March, 17 May and 29 September 1999). The results for the soluble $\mathrm{Pb}$ (Figure 8) reflect the great spatial variability of the contamination and reveal that the most effective reduction resulted with zeolites, iron, and the mixture of iron and zeolites. Because of the proximity of red soils in Aljarafe area (calcic Rhodoxeralf), with high amounts of free iron oxides and clays, these materials were selected as the best agents in the Pb-remediation treatments of the affected area.

\section{Conclusion}

The cleanup and tilling of the soils affected by the toxic spill from the pyrite mine in Aznalcóllar (S Spain) were insufficient measures in many sectors to reduce the 


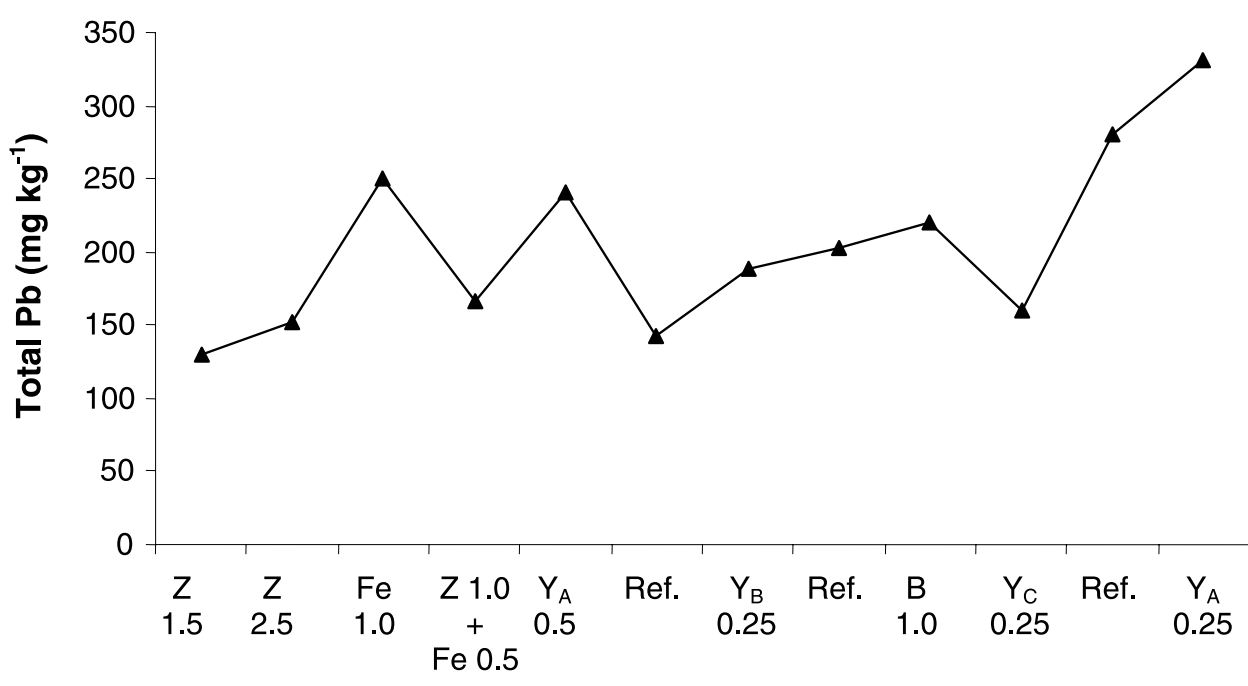

\section{Lending materials applied}

Figure 7. Total $\mathrm{Pb}$ concentrations $\left(\mathrm{mg} \mathrm{kg}^{-1}\right.$ ) in the experimental plots before the treatments ( 3 March 1999). (amendment materials: $\mathrm{Fe}=$ iron oxides, $\mathrm{Z}=$ zeolites, $\mathrm{B}=$ bentonites, $\mathrm{Y}=$ yeasts type $\mathrm{A}, \mathrm{B}$ and $\mathrm{C}$; the number accompanying the symbol indicates the application rate in $\mathrm{kg} \mathrm{m}^{-2}$; Ref. $=$ reference plot, untreated).

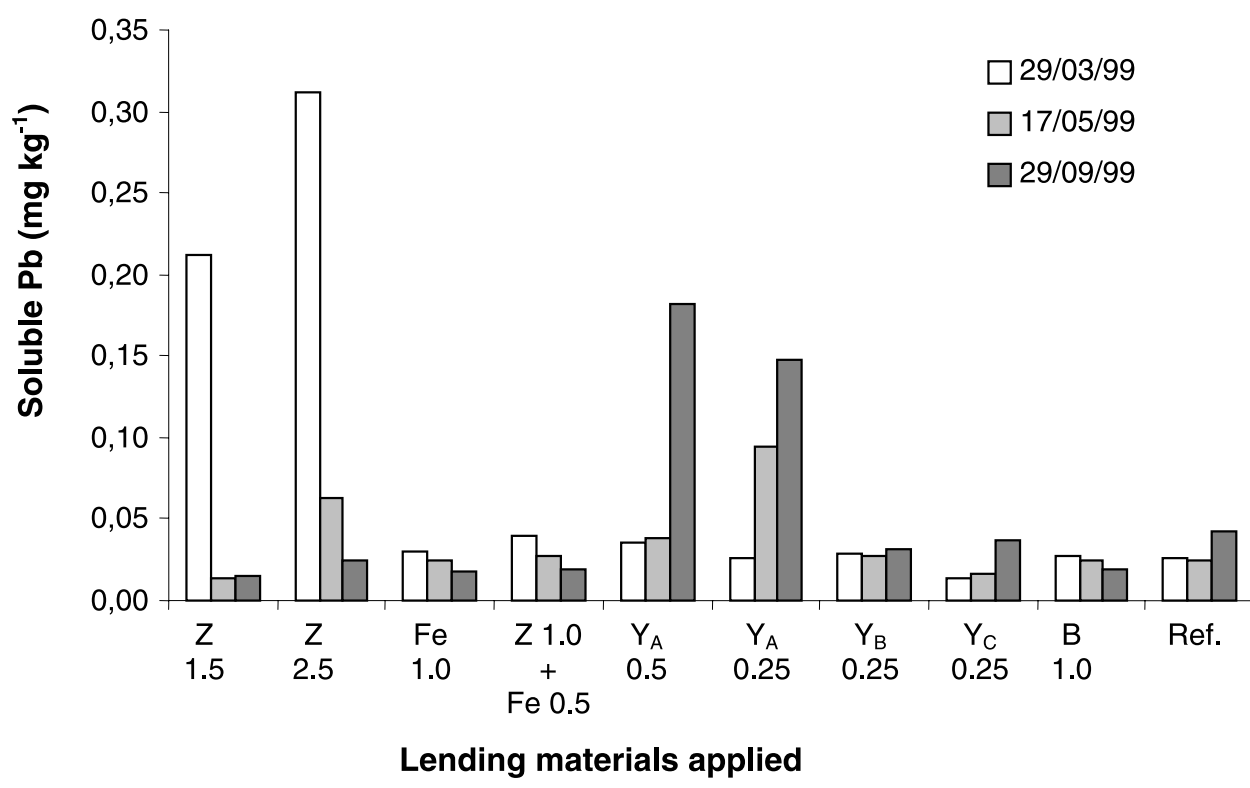

Figure 8. Soluble $\mathrm{Pb}\left(\mathrm{mg} \mathrm{kg}^{-1}\right)$ in the experimental plots in the three sampling dates (amendment materials: $\mathrm{Fe}=$ iron oxides, $\mathrm{Z}=$ zeolites, $\mathrm{B}=$ bentonites, $\mathrm{Y}=$ yeasts type $\mathrm{A}, \mathrm{B}$ and $\mathrm{C}$; the number accompanying the symbol indicates the application rate in $\mathrm{kg} \mathrm{m}^{-2} ;$ Ref. = reference plots, untreated). 
$\mathrm{Pb}$ concentration to below the permitted limits for agricultural soils. According to our results, the most important soil property in $\mathrm{Pb}$ retention was $\mathrm{CaCO}_{3}$ content. The initial application rate of $2 \mathrm{~kg} \mathrm{~m}^{-2}$ of carbonate amendment material (sugarrefinery scum) would be insufficient to neutralize the sulphur remaining in soil. Therefore, this treatment should be repeated 6 or 7 times in order to reach stable neutralization. The experiments to identify the other compounds indicate that freeiron oxides, supplied by the red soils of the Aljarafe area, were the most effective in the $\mathrm{Pb}$ retention.

\section{Acknowledgements}

The authors express their gratitude to the Environmental Ministry of the Regional Government of Andalusia, Spain, for its financial support that made this work possible. Also thanks go to Mr. David Nesbitt for the English translation and comments.

\section{References}

Adriano, D. C., Chlopecka, A., Kaplan, D. L., Clijsters, H. and Vangronsveld, J.: 1997, 'Soil Contamination and Remediation: Philosophy, Science and Technology', in Prost (ed.), Contaminated Soils, INRA, Paris, pp. 465-504

Aguilar, J., Dorronsoro, C., Gómez Ariza, J. L. and Galán, E.: 1999, 'Los criterios y estándares para declarar un suelo contaminado en Andalucía y la metodología y toma de muestras y análisis para su investigación', in Univ. Sevilla (ed.), Investigación y Desarrollo Medioambiental en Andalucía, Univ. Sevilla, Sevilla, Spain, pp. 45-59.

Bascomb, C. L.: 1961, 'A calcimeter for routine use on soil samples', Chem. Ind. 45, 1826-1827.

CSIC-IARA: 1998, 'Informes científicos sobre el seguimiento del accidente de Aznalcóllar', 9 Technical Reports, Consejería de Medio Ambiente, Junta de Andalucía, Sevilla, Spain, pp. 64.

Ewers, W.: 1991, 'Standars, Guidelines and Legislative Regulatory Concerning Metals and their Compounds', in E. Merian (ed.), Metals and their Compounds in the Environment, VCR Publishers, Weinheim, Germany, pp. 707-711.

GRER (Giunta Regionale dell'Emilia-Romagna): 1996, 'Leggi Regionale in Materia di Igiene ,del Suolo e Smaltimento dei Rifiuti', 1183 del 24/5/96, LR 27/94, Art. 33, Roma, Italy.

Holmgren, G.: 1967, 'A rapid citrate-dithionite extractable iron procedure', Sci. Soc. Am. Proc. 38, 647-652.

Kloke, A., Sauerbeck, D. R. and Vetter, H.: 1994, 'The Contamination of Plants and Soils with Heavy Metals and Transport of Metals in Terrestrial Food Chains', in J. O. Nriagu (ed.), Changing Metal Cycles and Human Health, Springer-Verlag, Berlin, Germany, pp. 113-141.

Loveland, P. J. and Whalley, W. R.: 1991, 'Particle Size Analysis', in K. A. Smith and Ch. E. Mullis (eds.), Soil Analysis: Physical Methods, Marcel Dekker, New York, U.S.A., pp. 271-328.

Quevauviller, Ph., Lachica, M., Barahona, E., Gómez, A., Rauret, G., Ure, A. and Muntau, H.: 1998, 'Certified reference material for the quality control of EDTA- and DTPA-extractable trace metal contents in calcareous soils (CRM 600)', Presenius. J. Anal. Chem. 360, 505-511.

Sheppard, S. C., Gaudet, C., Sheppard, M. L., Cureton, P. M. and Wong, M. P.: 1992, 'The development of assessment and remediation guidelines for contaminated soils, a review of the science', Can. J. Soil Sci. 75, 359-394. 
Simón, M., Ortiz, I., García, I., Fernández, J., Fernández, E., Dorronsoro, C. and Aguilar, J.: 1998, 'El desatre ecológico de Doñana', Edafología. 5, 153-161.

Simón, M., Ortíz, I., García, I., Fernández, J., Fernández, E., Dorronsoro, C. and Aguilar, J.: 1999, 'Pollution of soils by the toxic spill of a pyrite mine (Aznalcollar, Spain)', The Sci. of the Total Environ. 242, 105-115.

Simón, M., Martín, F., Ortíz, I., García, I., Fernández, J., Fernández, E., Dorronsoro, C. and Aguilar, J.: 2001, 'Soil pollution by oxidation of tailings from toxic spill of a pyrite mine', The Sci. of the Total Environ. 279, 63-74.

Soil Survey Staff: 1951, Soil Survey Manual, Handbook 18, USDA, Washington DC, pp. 227.

Sposito, G., Lund, L. J. and Chang, A. C.: 1982, 'Trace metal chemistry in arid-zone field soils amended with sewage sludge: Fractionation of $\mathrm{Ni}, \mathrm{Cu}, \mathrm{Zn}, \mathrm{Cd}$ and $\mathrm{Pb}$ in solid phases', Soil Sci. Soc. Am. J. 46, 260-264.

USDA: 1999, Soil Taxonomy. A Basic System of Soil Classification for Making and Interpreting Soil Surveys, Agriculture Handbook 436, 2nd ed., United States Department of Agriculture, Natural Resource Conservation Service, Soil Survey Staff, Washington DC, pp. 869.

Urrutia, M. M., García Rodeja, E. and Macías, F.: 1992, 'Sulphide oxidation in coal-mine dumps: Laboratory measurement of acidifying potential with $\mathrm{H}_{2} \mathrm{O}_{2}$ and its application to characterize spoil materials', Env. Manag. 16, 86-89. 